\title{
The effect of different concentrate: Lucerne hay ratio on crude protein degradation of various feeds using in situ technique
}

Mohsen Danesh Mesgaran, Alireza Vakili, Alireza Heravi Mousavi

Ferdowsi University of Mashhad, Mashhad, Iran

Email:danesh@um.ac.ir

Introduction Available information on the effect of ruminal $\mathrm{pH}$ on degradation of crude protein of various feeds is scarce. It has been reported that in a high concentrate diets, protein degradation is usually reduced (Molero et al., 2004). This reduction has been attributed to lower ruminal $\mathrm{pH}$, which causes the changes in protein solubility (Loerch et al., 1983) and reduces fibrolytic activity of rumen microflora. There is also limited information concerning the requirements for rumen degradable $\mathrm{N}(\mathrm{RDN})$ when high-grain diets are given to steers, and most of that information has been obtained using urea as the source of RDN. The aim of the present experiment was to evaluate the effect of different concentrate to lucerne hay ratios $(60: 40,70: 30,80: 20$ or 90:10) on ruminal crude protein degradation kinetic of lucerne hay, barley grain, soybean meal and fish meal.

Materials and methods The experimental feeds were lucerne hay, barley grain, soybean meal and fish meal. Samples were dried using a forced-air oven at $96{ }^{\circ} \mathrm{C}$ for $48 \mathrm{~h}$. All feed samples were ground to pass through a 2-mm screen, then, analyzed for total $\mathrm{N}$ (Kjeldahl method). The samples were incubated in the rumen of four Holstein steers $(300 \pm 15 \mathrm{~kg}$ body weight) with ruminal fistulae. Animals were fed $6.8 \mathrm{~kg}$ of DM of diets (2 times per day) differing in concentrate (155 g CP $\mathrm{kg}^{-1}$ of DM; $30 \%$ maize, $34 \%$ barley, $8 \%$ soybean meal, $5 \%$ sugar beet pulp, $10 \%$ wheat bran, $12 \%$ cottonseed meal, $0.3 \%$ $\mathrm{CaCo3}, 0.5 \%$ mineral and vitamin premix, 0.2\% salt) to lucerne hay ratios as $60: 40\left(\mathrm{C}_{60}: \mathrm{L}_{40}\right), 70: 30\left(\mathrm{C}_{70}: \mathrm{L}_{30}\right), 80: 20$ $\left(\mathrm{C}_{80}: \mathrm{L}_{20}\right)$ and $90: 10\left(\mathrm{C}_{90}: \mathrm{L}_{10}\right)$ in a $4 \mathrm{X} 4$ Latin square design (28 days of each period). Samples $(5 \mathrm{~g}$ DM) were placed in artificial silk bags $(10 \times 20 \mathrm{~cm}, 50 \mu \mathrm{m}$ pore size $)$ and incubated in the rumen for $0.0,2,4,8,16,24,48,72$ and $96 \mathrm{~h}(\mathrm{n}=8)$ in each period. In addition, the $\mathrm{pH}$ of the ruminal fluid samples was measured with a portable $\mathrm{pH}$ meter before the morning feeding to 8 hours post feeding (interval $15 \mathrm{~min}$ ) at days of 24 to 28 on each period. Data of CP degradation beyond the lag-time were further adjusted to a negative exponential model $\left[\mathrm{P}=\mathrm{a}+\mathrm{b}\left(1-\mathrm{e}^{\mathrm{ct}}\right)\right.$, where $\mathrm{P}=$ fraction degraded in the time $\mathrm{t}$, $\mathrm{a}=$ rapidly degradable fraction, $\mathrm{b}=$ slowly degradable fraction, $\mathrm{c}=$ fractional degradation rate and $\mathrm{t}=$ incubation time $]$. Effective degradability of CP (out flow rate $=0.08 / \mathrm{h}$ ) of the feed samples was also calculated. All data were subjected to least squares ANOVA using the GLM procedure of SAS at $\mathrm{p}<0.05$.

Results Minimum daily ruminal $\mathrm{pH}$ decreased from $6.40\left(\mathrm{C}_{60}: \mathrm{L}_{40}\right)$ to $5.34\left(\mathrm{C}_{90}: \mathrm{L}_{10}\right)$. The results showed that the $\mathrm{CP}$ degradation parameters of the feeds are influenced by the diet composition (Table 1).

Table 1 In situ CP degradation parameters (Mean \pm SE) of various feeds determined in steers fed diets differing in concentrate to lucerne hay ratios

\begin{tabular}{lcccccc}
\hline \multirow{2}{*}{ Feeds } & Parameter* & \multicolumn{3}{c}{ Concentrate:lucerne hay ratio $\dagger$} \\
\cline { 3 - 6 } & & $60: 40$ & $70: 30$ & $80: 20$ & $90: 10$ & SEM \\
\hline \multirow{2}{*}{ Lucerne hay } & $\mathrm{a}$ & $0.39 \pm 0.01$ & $0.38 \pm 0.01$ & $0.40 \pm 0.01$ & $0.40 \pm 0.01$ & 0.01 \\
& $\mathrm{~b}$ & $0.44 \pm 0.02$ & $0.49 \pm 0.01$ & $0.41 \pm 0.01$ & $0.45 \pm 0.01$ & 0.01 \\
\multirow{5}{*}{ Barley grain } & $\mathrm{c}$ & $0.07 \pm 0.01$ & $0.06 \pm 0.01$ & $0.08 \pm 0.01$ & $0.06 \pm 0.01$ & 0.01 \\
& $\mathrm{a}$ & $0.21 \pm 0.04$ & $0.25 \pm 0.03$ & $0.30 \pm 0.03$ & $0.21 \pm 0.05$ & 0.04 \\
& $\mathrm{~b}$ & $0.61 \pm 0.04$ & $0.57 \pm 0.03$ & $0.55 \pm 0.04$ & $0.61 \pm 0.05$ & 0.03 \\
Soybean meal & $\mathrm{c}$ & $0.14 \pm 0.03$ & $0.23 \pm 0.03$ & $0.12 \pm 0.02$ & $0.17 \pm 0.04$ & 0.03 \\
& $\mathrm{a}$ & $0.05 \pm 0.02$ & $0.06 \pm 0.02$ & $0.05 \pm 0.02$ & $0.07 \pm 0.05$ & 0.03 \\
& $\mathrm{~b}$ & $0.62 \pm 0.15$ & $0.89 \pm 0.16$ & $0.72 \pm 0.13$ & $0.56 \pm 0.08$ & 0.09 \\
Fish meal & $\mathrm{c}$ & $0.02 \pm 0.01$ & $0.01 \pm 0.01$ & $0.02 \pm 0.01$ & $0.04 \pm 0.02$ & 0.01 \\
& $\mathrm{a}$ & $0.19 \pm 0.01$ & $0.19 \pm 0.01$ & $0.18 \pm 0.01$ & $0.17 \pm 0.01$ & 0.01 \\
& $\mathrm{~b}$ & $0.51 \pm 0.05$ & $0.47 \pm 0.03$ & $0.44 \pm 0.02$ & $0.43 \pm 0.02$ & 0.02 \\
& $\mathrm{c}$ & $0.03 \pm 0.01$ & $0.03 \pm 0.01$ & $0.04 \pm 0.01$ & $0.04 \pm 0.01$ & 0.01 \\
\hline
\end{tabular}

*: $a=$ rapidly degradable fraction, $b=$ slowly degradable fraction, $c=$ fractional degradation rate; $\dagger:$ When the difference between means is greater than two times the SEM, it is considered as significant $(\mathrm{P}<0.05)$.

Conclusions In the present study, diet composition significantly affected the degradation parameters, when ruminal CP degradation of the various feed samples were considered. Therefore, the extent of ruminal CP degradation is a function of rumen $\mathrm{pH}$. The effect being more pronounced on the fractional degradation rate $(c)$, when barley grain was evaluated. This parameter was stimulated by $\mathrm{C}_{70}: \mathrm{L}_{30}$, but, decreased when the animals fed $\mathrm{C}_{80}: \mathrm{L}_{20}$. In general, effective degradability of $\mathrm{CP}$ of the feed samples was decreased when animals fed $\mathrm{C}_{90}: \mathrm{L}_{10}$.

\section{References}

Loerch, S. C., Berger, L. L., Gianola, D. and Fahey Jr., G.C., 1983. Effects of dietary protein source and energy level on in situ nitrogen disappearance of various protein sources. Journal of Animal Science. 56: 206-216.

Molero, R., Ibars, M., Calsamiglia, S., Ferret, A. and Losa, R., 2004. Effects of a specific blend of essential oil compounds on dry matter and crude protein degradability in heifers fed diets with different forage to concentrate ratios. Animal Feed Science and Technology. 114: 91-104. 